\author{
Arkadiusz Barut \\ ORCID: 0000-0002-9347-7072 \\ Uniwersytet Wrocławski
}

\title{
Od prawa naturalnego do praw człowieka. Ewolucja idei praw naturalnych w europejskiej myśli prawno-politycznej
}

Abstrakt: Przedmiotem niniejszego tekstu jest analiza procesu przekształcania się idei prawa naturalnego w ideę uprawnień naturalnych, która miała miejsce w europejskiej myśli prawno-politycznej od starożytności grecko-rzymskiej do XVII wieku i ostatecznie - w XVIII wieku — doprowadziła do powstania idei praw człowieka. Autor koncentruje się na szczególnie istotnych aspektach tej ewolucji - przejściu od idei prawa jako rozumnego porządku do jego pojmowania jako wyrazu woli, rezygnacji z uzasadniania prawa metafizycznie celami ludzkiej natury na rzecz jego uzasadniania ludzkimi pragnieniami, wreszcie uznaniu uprawnień naturalnych za źródło legitymacji i kryterium kontroli władzy politycznej. Na koniec autor odwołuje się do koncepcji Hannah Arendt, która wskazywała, że uznanie za źródło porządku politycznego praw pojmowanych jako niezależne od instytucji umożliwiających działanie polityczne prowadzi do destabilizacji sfery publicznej, utożsamienia władzy z przemocą, a w rezultacie do zaniku indywidualności, jaki miał miejsce w totalitaryzmie.

Słowa kluczowe: prawo naturalne, uprawnienia naturalne, prawa podmiotowe, prawa człowieka

From natural law to human rights. The evolution of the idea of natural rights in European legal and political ideas

Abstract: The subject of the article is the transformation of the idea of natural law into the idea of natural rights, which took place in Europe between Greek and Roman Antiquity and the 17th century, the last stage of this process was the origin of the idea human rights in the 18th century. The author focuses on the most important aspects of this evolution: the transition from the understanding of law as a rational order to its conception as an expression of will, giving up the justification of law by human natural goals and taking up its justification by human desires. Finally, the author refers to the conception of Hannah Arendt, who argued that the identification of the source of political order with subjective rights, understood as pre-political, leads to the destabilization of the political 
sphere and the identification of authority with violence. The result is the extinction of individuality, which took place in totalitarian regimes.

Keywords: natural law, natural rights, subjective rights, human rights

\section{Od prawa naturalnego jako obiektywnego porządku do idei uprawnień naturalnych}

Podstawowa różnica między klasyczną ideą prawa naturalnego a ideą uprawnień naturalnych polega na tym, że - jak uważa między innymi Jurgen Habermas - prawo naturalne wyraża zasady konieczne do cnotliwego życia, uprawnienia naturalne zaś ustanawiają sferę swobodnego wyboru ${ }^{1}$. Starożytność grecko-rzymska koncentrowała się nie na uprawnieniach naturalnych, lecz na prawie naturalnym, pojętym jako obiektywny porządek rzeczy. W refleksji antycznej oraz u późniejszych myślicieli przez nią zainspirowanych można wyróżnić dwie odmiany koncepcji prawa naturalnego jako obiektywnego porządku (dikaion phusikon, ius naturale): jego pojmowanie jako ponadczasowej idei lub jako ustalonej praktyki dobrego społeczeństwa. Tak rozumiane prawo naturalne nie jest różne od sprawiedliwości. Platon uznawał za prawo (we właściwym tego słowa znaczeniu) ponadczasową ideę sprawiedliwości. Stoicy, twórcy pojęcia prawa naturalnego, identyfikowali je z obiektywnymi, rozumnymi zasadami rządzącymi światem. U Arystotelesa sprawiedliwość (w sensie „ciaśniejszym” ${ }^{2}$ ) to stan właściwego rozdzielenia dóbr między ludzi żyjących pod wspólną władzą polityczną ${ }^{3}$. Święty Tomasz z Akwinu, łącząc te dwie tradycje, wprowadza rozróżnienie na prawo wieczne, samoistnie istniejące prawo boskie, lex aeterna, oraz prawa w nim uczestniczące - naturalne, ludzkie i boże (boskie prawo objawione) - lex naturalis, lex humana, lex divina ${ }^{4}$. Nie ma tu miejsca, by rozstrzygać, kiedy jus pojmowane jako obiektywny porządek staje się jus pojmowanym jako uprawnienie naturalne. Brian Tierney jako prekursorów idei praw subiektywnych wskazuje dwunastowiecznych specjalistów od prawa ka-

\footnotetext{
1 J. Habermas, Theory and Practice, przeł. J. Viertel, Boston 1974, s. 84.

2 Arystoteles wyróżniał też sprawiedliwość w sensie ogólnym jako ogólnie pojętą cnotę, stałą dyspozycję do działania sprawiedliwego - idem, Etyka, ks. V, 1129a; podobnie święty Tomasz z Akwinu, Suma Teologiczna, t. 18, 2-2, zagadnienie 58.

${ }^{3}$ U Arystotelesa przedmiotem prawa są stosunki między obywatelami - ibidem, ks. V, 1130b, 1134a. Z tego punktu widzenia sztuka prawodawcza oraz sądowa są rodzajem polityki - ibidem, ks. VI, 1142a.

${ }^{4}$ Jego zdaniem prawo naturalne jest niezmienne w swym podstawowym nakazie: czynienia dobra (uszczegółowionym przez konstatację naturalnych skłonności człowieka do zachowania życia, jego przekazywania, zdobywania wiedzy i życia w społeczności). Święty Tomasz, zbliżając się w ten sposób do poglądu Arystotelesa, wskazuje zarazem, że zastosowanie tych zasad zmienia się w zależności od konkretnych warunków - ibidem, t. 13, zagadnienie 91, art. 1-5; zagadnienie 94, art. 4-5.
} 
nonicznego ${ }^{5}$. Według Michela Villeya ideę uprawnień naturalnych sformułował William Ockham, który w wielkim sporze o zdefiniowanie prawa, jakie przysługuje franciszkanom do użytkowanych przez nich dóbr, określił jus jak władzę (potestas) jednostki, prawo zaś, w sensie obiektywnym, jako hierarchię potestates: od potestas Boga, poprzez potestates powierzone człowiekowi wprost przez Boga: iura poli (potestas aprioprandii, potestas instituendi rectores itd.) po potestates przyznane przez ludzkie prawo pozytywne: iura fori (dominium, ius utendi, ius vindicandi itd.) ${ }^{6}$. Richard Tuck decydującą rolę przypisuje Jeanowi Gersonowi, który pojmował jus jako władzę (facultas) indywidualnego bytu, a za jedną z nich (w przeciwieństwie do autorów antycznych) uznawał wolność (libertas) ${ }^{7}$.

Niewątpliwe jest jednak, że w pierwszej połowie XVII wieku ${ }^{8}$, w szczególności u Franciszka Suareza ${ }^{9}$ i Hugo Grocjusza ${ }^{10}$, spotyka się wyraźne odróżnienie pojęcia jus jako obiektywnego porządku rzeczy i jus jako uprawnienia naturalnego ${ }^{11}$. Dla Tomasza Hobbesa ius naturale to wyłącznie „wolność, jaką ma każdy człowiek, używania swej własnej mocy według swojej własnej woli dla zachowania własnej istoty”12. Podobnie, według Johna Locke’a, stan natury to dla ludzi „stan zupełnej wolności w działaniu oraz rozporządzaniu swymi majątkami oraz osobami, tak jak oni uznają za właściwe w granicach prawa natury, nie pytając nikogo o zezwolenie, bez zależności od woli innego człowieka"13.

${ }^{5}$ Według B. Tierneya idea prawa jako jus - sprawiedliwego stanu rzeczy i jako lex - normy współistniała od czasów klasycznych, w tym w chrześcijaństwie - idem, The Idea of Natural Rights: Studies on Natural Rights, Natural Law and Church Law 1150-1625, Cambridge 2001, s. 25.

${ }^{6}$ M. Villey, La formation de la pensée juridique moderne, Paris 2003, s. 264-267. Z jego poglądem o nowatorstwie Ockhama polemizują Brian Tierney (op. cit., s. 27-30) i Richard Tuck (Natural Right Theories, Lexington 2011, s. 22-24).

7 Podkreśla też rolę papieża Jana XXII, który w bulli Quia vir reprobus stwierdzał, że prawo własności jest prawem naturalnym, przysługującym nawet pierwszym rodzicom — ludziom w stanie przedspołecznym - R. Tuck, op. cit., s. 22. Autor w ewolucji pojęcia praw naturalnych duże znaczenie przypisuje podziałowi na prawa pasywne (prawa do świadczeń innych ludzi lub powstrzymywania się przez nich od działania) oraz prawa aktywne (takie jak prawo własności; prawa do podejmowania działania), przypisując tym ostatnim charakter nowożytny - ibidem, s. 5-7, 26.

${ }^{8}$ Według Tucka pewnym „regresem” była pierwsza połowa XVI wieku, gdy zorientowani humanistycznie filozofowie prawa wrócili do klasycznego pojęcia jus jako obiektywnego porządku rzeczy - ibidem, s. 32-50.

9 B. Tierney, op. cit., s. 50-51.

${ }^{10}$ H. Grocjusz, Trzy Księgi o Prawie Wojny i Pokoju, w których znajduja wyjaśnienie Prawo Natury i Prawo Narodów a także Główne Zasady Prawa publicznego, przeł. R. Bierzanek, Warszawa 1957, s. $88-89$.

11 Wcześniej rozróżnienie to wprowadzał Marsyliusz z Padwy; zob. B. Tierney, op. cit., s. 111114.

12 T. Hobbes, Lewiatan, czyli materia, forma i władza państwa kościelnego i świeckiego, przeł. C. Znamierowski, Warszawa 2009, s. 210.

13 J. Locke, Dwa traktaty o rządzie, przeł. Z. Rau, Warszawa 1992, s. 165. 


\section{Prawo jako rozporządzenie rozumu a prawo jako wyraz woli}

Jako źródło prawa naturalnego można postrzegać obiektywne wskazania rozumu lub uznawać za nie wolę. Nie ma wprawdzie koniecznego związku między uznaniem woli za źródło prawa a ideą uprawnień naturalnych - można przypisywać człowiekowi uprawnienia naturalne, składające się na całość rozumnego porządku świata (na co zwracają uwagę autorzy poszukujący ich źródeł w tomizmie), uznanie człowieka za istotę rozumną sprzyja zaś identyfikowaniu go z podmiotem praw $^{14}$. Przejście do idei jus jako uprawnienia podmiotowego nie byłoby jednak możliwe, gdyby w europejskiej tradycji prawnej nie uzyskało znaczenia podejście woluntarystyczne.

U Platona prawo jest odzwierciedleniem świata idei, których treść i wzajemne relacje mają charakter rozumny. Dla Arystotelesa prawo naturalne nie jest wiedzą w sensie naukowym (episteme), dlatego nie może być wyrażone w formie abstrakcyjnych reguł. To rodzaj poznania praktycznego ${ }^{15}$. Na gruncie jego koncepcji sprawiedliwość ma, zasadniczo, charakter zmienny, do jej skonkretyzowania potrzeba więc roztropności i woli wykształconej dzięki praktyce, tego co później Rzymianie nazwali jurysprudencją ${ }^{16}$. U świętego Tomasza podmiotem sprawiedliwości jest wola, która idzie jednak za poznaniem rozumu ${ }^{17}$. Ostatecznie w tradycji arystotelesowsko-tomistycznej dominuje racjonalizm — prawo to, jak pisze Tomasz, „rozporządzenie rozumu” ${ }^{18}$. Daje się ono rozumnie uzasadnić, chociaż przy założeniu ograniczoności indywidualnej racjonalności.

Chrześcijaństwo jako podstawowe źródło prawa wprowadza jednak wolę bożą, niepodlegającą osądowi ludzkiego rozumu ${ }^{19}$. W chrześcijaństwie prawo naturalne

${ }^{14}$ Na przykład u neoscholastyka Franciszka de Vitorii idea praw podmiotowych, w tym praw niechrześcijan - Indian (prywatnych i publicznych: własności, prawa do własnych rządów itd.), uzasadniona jest wyjątkową pozycją człowieka jako istoty racjonalnej. Nie wprowadza on już, jak wcześniej na przykład Jean Gerson, pojęcia praw (iura) przedmiotów nieożywionych - B. Tierney, op. cit., s. 265-272.

$15 \mathrm{Z}$ tego względu prawodawstwa można się nauczyć, tak jak polityki, jedynie dzięki praktyce Arystoteles, op. cit., ks. V, 1134b, 1181a-b. Arystotelesowskie prawo naturalne to nie zbiór reguł, lecz zasada metodologiczna; zob. C. Douzinas, The End of Human Rights, Oxford 2000, s. 40.

16 Sprawiedliwość ma charakter ogólny, zatem w konkretnym przypadku może być konieczne odejście od reguł generalnych i abstrakcyjnych wyrażonych w nomos na rzecz słuszności - Arystoteles, op. cit., ks. V, 1130b. Przekonanie o pomocniczym charakterze norm prawnych w poznaniu prawa wyrażali prawnicy rzymscy, jak stwierdzał Paulus: „non ex regula ius sumatur, sed ex iure quod est regula fiat" - zob. M. Villey, op. cit., s. 94.

17 Tomasz z Akwinu, op. cit., t. 18, 2-12, zagadnienie 58, art. 4.

18 Ibidem, t. 13, zagadnienie 90, art. 4.

19 Do odrębności tradycji klasycznej i judeochrześcijańskiej (a właściwie augustyńskiej) duże znaczenie przywiązuje Michel Villey. W judaizmie kosmos - natura nie były uznawane za samoistne źródło ładu; jako stworzone przez Boga ex nihilo objawiały Jego wolę, a nie samoistne cele bytów. Jego zdaniem rozwój europejskiej tradycji prawnej naznaczony jest przez dialektykę arystotelesowsko- 
zaczęło być z jednej strony identyfikowane ze światłem boskim oświecającym sumienia (list świętego Pawła do Rzymian 11:15), wskazaniami dostępnymi wszystkim ludziom (również poganom); z drugiej strony $-\mathrm{z}$ Dekalogiem i Ewangelią pojmowanymi jako zbiory norm (na przykład w Decretum Gratiana z XII wieku). U Augustyna kondycją upadłej ludzkości, w tym społeczeństw politycznych, jest niesprawiedliwość; sprawiedliwość pochodzi bowiem od Boga jako skutek łaski. Augustyn identyfikuje ją nie tyle z właściwym stanem relacji między ludźmi, lecz z oddaniem się człowieka Bogu, a zasada suum cuique tribuere znaczyć ma powierzenie się Jemu ${ }^{20}$.

Postrzeganie woli jako źródła prawa może skłaniać do uznania, że podmiotem prawa jest nie tylko Twórca obiektywnego porządku, lecz także jednostki. Formułuje się twierdzenie, że rozwój idei uprawnień naturalnych w XIV i XV wieku wiązał się bezpośrednio z koncepcją teologiczną, zgodnie z którą świat jest własnością Boga, a człowiek jest podmiotem własności na Jego podobieństwo ${ }^{21}$. Według Villeya Ockhamowskie pojmowanie jus jako potestas wynikało wprost z założenia nominalistycznego i idei wszechmocy Stwórcy ${ }^{22}$. Podkreślenie metafizycznego znaczenia wolnej woli prowadziło Luisa de Molinę i innych szesnastowiecznych

-rzymsko-tomistycznej idei jus jako właściwego stanu rzeczy oraz judeochrześcijańskiej idei prawa jako normy - Torah i lex. Krytykę tego stanowiska przeprowadza Brian Tierney (op. cit., s. 30-31). Wskazuje na dualistyczny, swoiście „manichejski” obraz świata przyjmowany przez Villeya, oparty na przeciwstawieniu „dobrej” tradycji prawa arystotelesowskiego „złej” tradycji identyfikującej go z system norm, co ostatecznie miało prowadzić do sprowadzenia go do uprawnień indywidualnych. Tierney polemizuje też z Villeyowskim pojmowaniem koncepcji prawnych jako bezpośrednio uwarunkowanych koncepcjami filozoficznymi i metafizycznymi. Jak uważa Tierney, nie ma na przykład prostej zależności między metafizyką arystotelesowską a odrzuceniem lub akceptacją idei uprawnień naturalnych, tak jak nie da się wykazać bezpośredniego związku między nominalizmem Ockhama a jego ideą jus jako potestas. Według Tierneya idea jus jako sprawiedliwego stanu rzeczy i prawa podmiotowego nie wyklucza się: sprawiedliwe jest, by dzieci szanowały rodziców, a zarazem rodzice mają prawo do takiego szacunku - ibidem, s. 32-33. Krytyka ta nie wydaje się umniejszać historiozoficznego znaczenia dzieła Villeya.

${ }^{20}$ M. Villey, op. cit., s. 107-138. Według niego prowadzi to nie tylko do podkreślenia ponadludzkiego charakteru sprawiedliwości i odmówienia przymiotu sprawiedliwości instytucjom ludzkim, lecz także, paradoksalnie, przypisania ziemskiemu legislatorowi suwerenności. Prawa państwa ziemskiego wymagają szacunku, ponieważ w pewien sposób zapewniają pokój (chociaż jego niedoskonałą formę w porównaniu do pokoju, który może dać Bóg, na przykład również poganie karali występki przeciw naturze), są wyrazem woli bożej (istnienie złej władzy kryje boży plan, na przykład męczeństwo pierwszych chrześcijan było możliwe dzięki władzy pogańskich cezarów), są wreszcie karą za grzechy. Ponadto ich przestrzeganie może wynikać z roztropności - ibidem, s. 119-120). Villey zwraca uwagę, że tego rodzaju uzasadnienie (wzgląd na porządek publiczny, bezpieczeństwo, szacunek dla faktu, sens historii) zbliżone jest do uzasadnienia pozytywizmu prawnego - ibidem, s. 120 . Podobnie u Platona zidentyfikowanie prawa $\mathrm{z}$ jego ideą prowadzi do pewnego rodzaju pozytywizmu. W Państwie, kreśląc ideę rządów filozofów, zakłada, że będą oni umieli wcielać ideę sprawiedliwości w każdych okolicznościach, prawa pisane schodzą więc na dalszy plan. Jednak w Polityku i Prawach prawa pisane nabierają znaczenia i pojawia się idea sędziego, wiernie wcielającego reguły prawne ibidem, s. 74-76.

${ }^{21}$ R. Tuck, op. cit., s. 30.

${ }^{22}$ M. Villey, op. cit., s. 225-227. 
myślicieli hiszpańskich do idei jus jako prawa „aktywnego” - prawa do suwerennego działania ${ }^{23}$. Hobbes za treść prawa naturalnego (lex naturalis) uznaje realizację woli przetrwania. Z tego względu za właściwe rozumienie słowa ,jus” przyjmie przestrzeń wolności, sferę nieregulowaną przez prawo przedmiotowe $-1 \mathrm{x}^{24}$. Jest to przejaw wyraźnego odróżnienia prawa jako obiektywnego porządku lub reguły od prawa jako przestrzeni wolności i odejście od założenia, że to obiektywna sprawiedliwość może ustanawiać indywidualne uprawnienia (wyrażona w stwierdzeniu świętego Tomasza, że lex ratio iuris). Według Villeya następuje w ten sposób całkowite zerwanie między ideą uprawnienia a ideą sprawiedliwości pojętej jako właściwy stan rzeczy, prawo zaś staje się wobec uprawnienia czynnikiem treściowo „zewnętrznym” ${ }^{25}$. Również Locke prezentuje woluntarystyczną koncepcję prawa natury - jako wyrazu woli Boga, a nie obiektywnego porządku rzeczy ${ }^{26}$. Przejście od stanu społeczności przedpolitycznych, tworzonych na skutek skłonności do życia z innymi ludźmi, do stanu społeczeństwa politycznego następować ma nie w sposób konieczny jako warunek spełnienia ludzkiej natury, lecz dzięki woli jednostek zmierzających do zachowania własności ${ }^{27}$.

\section{Idea uprawnienia naturalnego jako sposób dążenia do celu ponadindywidualnego a idea uprawnienia naturalnego jako środek zaspokajania pragnień}

Koncepcja dikaion u Platona i Arystotelesa czy jus u świętego Tomasza oparta była na idei człowieka jako bytu dążącego do celu, przekraczającego jego materialne potrzeby. Prawo oznaczało właściwy porządek rzeczy, wyznaczony według kryteriów rozumu ponadjednostkowego, to jest rozumu, który nie ma charakteru instrumentalnego wobec potrzeb jednostki; jej pragnienia podlegają więc uznaniu tylko w aspekcie tego nadjednostkowego celu. Nowożytne koncepcje uprawnień naturalnych mogą postrzegać je jako warunek konieczny do doskonalenia się jednost-

23 Autor przyjmuje rozróżnienie na kategorię praw aktywnych, do których istoty nie należy zachowanie innych, lecz swoboda działania uprawnionego, oraz pasywnych, których istotą jest zachowanie innych ludzi - R. Tuck, op. cit., s. 5, 50-57.

24 T. Hobbes, op. cit., s. 210-212.

25 Według Villeya wynika to z odrzucenia arystotelesowskiej metody polegającej na obserwacji życia społecznego na rzecz racjonalizmu apriorycznego oraz uznania, że wywodzi się ono ze stanu natury, w którym każdy ma, dla samozachowania, prawo do wszystkiego - idem, op. cit., s. 568-618.

26 Choć Locke w Drugim traktacie o rządzie sugeruje związanie Opatrzności prawami natury (op. cit., s. 302), ostatecznie, zdaniem Zbigniewa Raua, nigdy nie przełamuje zasady woluntaryzmu bożego (Z. Rau, Wstęp, [w:] J. Locke, op. cit., s. XXIX).

27 J. Locke, op. cit., s. 222-225. 
$\mathrm{ki}^{28}$. Typowo nowożytne uprawnienie naturalne ostatecznie jednak wyprowadzone zostało z prawa do samozachowania ${ }^{29}$.

Już u początków rozwoju idei uprawnień naturalnych można wyróżnić praktycystyczny aspekt ich uzasadniania. Gerson, formułując argumenty koncyliarystyczne na rzecz praw duchowieństwa do dóbr materialnych (a przez to broniąc jego pozycji wobec papieża), wskazywał, że gdyby uznać (jak chciał John Wycliff), że grzeszni duchowni nie mają tych praw, to nikt nie byłby pewny, co się komu należy, zapanowałaby więc anarchia ${ }^{30}$. Podobny argument praktycystyczny występuje u Grocjusza - należy dotrzymywać obietnic (w tym umów), gdyż jest to użyteczne dla ludzkiej kooperacji ${ }^{31}$. Na otwarcie antyteleologicznych przesłankach opierają się Hobbes i Locke. Pierwszy wyszedł z założenia, że w celu uniknięcia klęsk, jakich doznała klasyczna filozofia polityczna (czego w swoim mniemaniu był świadkiem we współczesnej mu Anglii), należy odnaleźć przesłankę najpewniejszą i niewątpliwą ${ }^{32}$. Wyszedł więc od przesłanki instynktu samozachowania, jedynej w swoim mniemaniu pewnej zasady, która jednak, jak uważa Leo Strauss, u wcześniejszych konwencjonalistów miała charakter niepolityczny ${ }^{33}$. Według Straussa różnica między obiektywnym jus klasycznym a jus nowożytnym wynika

28 Na przykład u Christiana Wolffa. Zob. B. Tierney, op. cit., s. 51.

29 Można też artykułować ideę jus jako prawo podmiotowe, a zarazem uznawać je za drugorzędne wobec obiektywnego porządku rzeczy — ten aspekt wyraźny jest u Gersona, który przypisywał prawa również zwierzętom i przedmiotom nieożywionym (na przykład słońce ma „prawo” świecić — ibidem, s. 227). W tym znaczeniu jus oznaczało więc pochodną natury danego bytu, a nie jego kwalifikację moralną.

30 Ibidem, s. 230, 231.

${ }^{31}$ R. Tuck, op. cit., s. 69-70. Jak uważa M. Villey, wnioski, jakie Grocjusz wyprowadza z reguł prawa naturalnego, wskazanych przez niego jako podstawowe (umów należy dotrzymywać, szkody naprawiać, przestępstwa karać i szanować własność), nie wynikają z nich w sposób konieczny. Aby nie dojść do wywrotowych konkluzji, opiera się na powszechnym mniemaniu i praktyce swych czasów. W ten sposób uzasadnia aneksje i większość innych, istniejących wówczas instytucji prawno-politycznych - idem, op. cit., s. 551-552.

32 Przesłanką tą, ze względu na wyznawaną mechanistyczną filozofię przyrody, nie mógł być teleologizm antropologiczny. Poza tym wiedza, do której chciał dojść Hobbes, miała umożliwić opanowanie świata, a nadto, jak już wskazano, musiała być pewna, na podobieństwo matematyki, jedynej dziedziny wiedzy, która, jako ludzka konwencja, zdolna jest odeprzeć ataki sceptycyzmu. Zob. L. Strauss, Prawo naturalne w świetle historii, przeł. T. Górski, Warszawa 1969, s. 160-162. Strauss zauważa sprzeczności w doktrynie Hobbesa, co sprawiać ma, że jawi się ona jako oderwana od jakichkolwiek konstatacji co do natury człowieka; jest więc konstrukcją teoretyczną, tak jak hipotezy naukowe, prawomocną, tylko na gruncie własnych przesłanek. Hobbes swój wywód wyprowadza z założenia, że najpotężniejszą, to znaczy najbardziej realną, ludzką skłonnością jest chęć samozachowania, obawa przed śmiercią. Zarazem jednak konstatuje, że niekiedy większy od tej obawy jest lęk przed mocami nadprzyrodzonymi (religia itd.) Stwierdza więc, że drogą wychowania ten drugi rodzaj obawy, jako szkodzący w procesie budowania stabilnego i „racjonalnego” systemu politycznego, będzie można wykorzenić - idem, op. cit., s. 181-186.

${ }^{33}$ Hobbes, według Straussa, połączył dwie tradycje: idealizm polityczny — przekonanie, że istnieje ustrój właściwy, niezależny od ustrojów rzeczywiście funkcjonujących, oraz konwencjonalizm, który aż dotąd (na przykład w postaci konwencjonalizmu sofistów czy Epikura) nie miał charakteru politycznego w tym sensie, że nie wskazywał przyjemności jako pierwszej przesłanki rozumowania 
Z odwrócenia uwagi od idei celów, a zwrócenia jej ku scjentystycznej idei środków $^{34}$. Skutkiem jest swoista „demokratyzacja” prawa naturalnego — każdy, nawet nierozumny, sam decyduje, co jest konieczne dla jego samozachowania. Wybór ten staje się prawomocny przez powstanie władzy politycznej. U Locke’a podstawową, naturalną skłonnością ludzką jest dążenie do szczęścia i unikanie cierpienia; elementarną zasadą prawa natury jest więc $-\mathrm{w}$ aspekcie powszechnym - nakaz zachowania gatunku ludzkiego, a w aspekcie indywidualnym — nakaz zachowania własnego życia. Implikuje to prawo do nabywania własności ${ }^{35}$. To nakaz zachowania życia ludzkiego implikuje więc nakaz zachowania społeczeństwa ${ }^{36}$.

\section{Uprawnienie naturalne jako źródło porządku politycznego}

W czasach przednowożytnych, o ile nawet uznawano, że porządek polityczny powinien umożliwiać indywidualną swobodę działania (przykładem: mowa pogrzebowa ku czci poległych Ateńczyków wygłoszona przez Peryklesa), co do zasady odrzucano jednak twierdzenie, że istnieje on wyłącznie dla niej. W nowożytności natomiast prawa indywidualne uzasadniają istnienie i sposób powstania społeczeństwa politycznego. Ideałem sprawiedliwego społeczeństwa nie jest społeczność, w której panuje sprawiedliwość jako obiektywny stan rzeczy, ale społeczeństwo, w którym respektowane są prawa indywidualne ${ }^{37}$. Dobitnie wyraził to

politycznego, a jedynie chciał dawać wskazówki co do warunków szczęśliwego życia jednostek ibidem, s. 155-156.

${ }^{34}$ Ibidem, s. 166-168, 181-186.

35 J. Locke, op. cit., s. 135, 166-167, 258-259. Podstawowa zasada prawa natury brzmi więc: „każdy, tak jak jest zobowiązany do zachowania samego siebie i nieopuszczania rozmyślnie swego miejsca kiedy jego własne samozachowanie nie jest wystawione na szwank, powinien także, według swych możliwości, zachować resztę rodzaju ludzkiego” - ibidem, s. 167. Z tego względu „nikt nie ma absolutnej, arbitralnej władzy nad sobą samym ani nad kimkolwiek innym, by mógł sam sobie odebrać życie lub odebrać życie bądź pozbawić życia lub własności kogoś innego" - ibidem, s. 258.

${ }^{36}$ Z. Rau podkreśla, że wskazanie nakazu samozachowania jako podstawowej zasady prawa natury nie jest u Locke’a, jak sądzą niektórzy, zawieszone w próżni etycznej. Zauważa też, że we wczesnym dziele pod tytułem Essays on the Law of Nature Locke stwierdzał, że stosunkami między ludźmi (nie tylko w społeczeństwie politycznym) winna rządzić złota zasada - idem, op. cit., s. XXXII-XXXIII. Tym niemniej nie można zaprzeczyć, że Locke wychodzi jednak nie od celu człowieka (osiągnięcia doskonałości etycznej poprzez życie w polis czy zjednoczenia się z Bogiem), lecz od konstatacji natury faktycznej. Nie może tego zmienić okoliczność, że — według Locke’a — samozachowanie jest zgodne z zamysłem Boga i realizuje cel wyznaczony przez Boga - ibidem, s. 86-87; por. Z. Rau, op. cit., s. XXXII; człowiek został bowiem stworzony dla przyjemności Stwórcy — J. Locke, op. cit., s. 166-167.

37 Początki takiego pojmowania społeczeństwa politycznego mają być widoczne już w średniowieczu. B. Tierney podkreśla związki między Gersonowską ideą praw podmiotowych a koncyliaryzmem - idem, op. cit., s. 220-225. 
Locke, wskazując, że aby „właściwie zrozumieć władzę polityczną i wyprowadzić ją z jej źródła", należy wyjść od pierwotnego stanu wolności i równości ${ }^{38}$.

Zarysowuje się w ten sposób nowy związek prawa z polityką. Skutkiem wyprowadzania porządku politycznego z prawa indywidualnego jest pojmowanie tego pierwszego jako wielkiej, powszechnej umowy. Może to prowadzić do uznania istnienia sfery niezależności obywateli od państwa (pojętego na sposób nowożytny). U Locke’a z chwilą wejścia do społeczeństwa obywatelskiego człowiek jawi się jako bardziej zagrożony przez władzę polityczną niż przez współobywateli, dlatego wolność negatywna ma u niego raczej charakter polityczny — jest wolnością od arbitralnej ingerencji władzy ${ }^{39}$.

Oparcie legitymizacji na uprawnieniu może też prowadzić do idei nieograniczoności woli władcy i uzasadniać wyłączenie prawa do oporu wobec władzy politycznej, możliwego do uzasadnienia na gruncie teorii, które uznawały prawo naturalne za sprawiedliwy porządek rzeczy. U Arystotelesa wola ustawodawcy (sędziego itp.) kierującego się sprawiedliwością ma samoistną wartość: skoro naturalne jest społeczeństwo, naturalne są również rządzące nim reguły. Oznaką sprawiedliwości człowieka jest przestrzeganie prawa pozytywnego, które zwykle nakazuje zachowanie sprawiedliwe i ma na celu kształtowanie dobrych obywateli ${ }^{40}$. Nie znaczy to jednak, by na gruncie tradycji perypatetyckiej każde prawo pozytywne zasługiwało na miano prawa - nie jest takim prawo niewątpliwie łamiące zasady sprawiedliwości, ewentualnie wydane przez podmiot nieuprawniony. Według świętego Tomasza prawo pozytywne, by mogło się rzeczywiście nazywać prawem, musi być zgodne z prawem naturalnym. Racjonalny charakter prawa decyduje o tym, że nie każde prawo ludzkie wiąże w sumieniu, co może usprawiedliwiać stawienia oporu władcy ${ }^{41}$.

Uzasadnienie porządku społecznego i politycznego umową oraz podkreślenie woli jako źródła sytuacji prawnych może prowadzić do konstatacji, że dopuszczalne jest zrzeczenie się swej wolności zarówno w sferze prawa prywatnego (takie stanowisko, jak na przykład u Moliny, może uzasadniać niewolnictwo $)^{42}$, jak i publicznego. Skoro lud, jak wskazuje Grocjusz, powierzając rządzenie władcy, prze-

38 J. Locke, op. cit., traktat II, par. 4.

39 Ibidem, s. 258-259; por. Z. Rau, op. cit., s. LXVIII. Według L. Straussa w Locke’owskim stanie natury nie może obowiązywać prawo natury, ponieważ prawo to nie ma skutecznej sankcji, a zatem w rzeczywistości nie jest prawem. Przestrzeganie prawa natury jest możliwe dopiero w społeczeństwie obywatelskim. W tym sensie Lockeowski stan natury jest podobny do stanu opisanego przez Hobbesa - L. Strauss, op. cit., s. 205-209. Strauss widzi też podobieństwa w określeniu pozycji państwa. Locke zastrzega, niewątpliwie, że ludzie muszą zachować wobec niego uprawnienie do obrony życia i własności, ponieważ jest to bardziej skuteczny sposób ich ochrony niż przekazanie ich w całości Lewiatanowi. Tym niemniej, w niektórych kwestiach związanych z prawem do samozachowania, takich jak służba wojskowa, Hobbes przyznaje ludziom więcej swobody w przeciwstawianiu się państwu niż Locke. Zob. ibidem, s. 213-214.

40 Arystoteles, op. cit., ks. V, 1129b, 1130b.

41 Tomasz z Akwinu, op. cit., t. 13, zagadnienie 96, art. 4.

42 R. Tuck, op. cit., s. 54. 
kazuje mu swoje uprawnienia, to nie ma już później prawa do oporu ${ }^{43}$. Wreszcie u Hobbesa nieograniczoność praw ludzi w stanie naturalnym uzasadnia nieograniczoność praw suwerena, któremu przekazali oni swe uprawnienia konieczne do samozachowania (dopóki może on w takiej roli efektywnie występować). Skoro suweren wykonuje ich własne prawa, nie mogą oni sensownie twierdzić, że dysponują prawem do oporu przeciw ich własnym uprawnieniom ${ }^{44}$. Jeśli utożsamia się wolę państwa $\mathrm{z}$ wolą obywateli, należy przyjąć, że władza nie jest powierzona rządzącym, ale wynika z samego prawa - jest własną wolą rządzonych ${ }^{45}$.

Do konstatacji o absolutności władzy politycznej może też prowadzić przypisanie uprawnieniom naturalnym charakteru moralnej ważności. U Arystotelesa istniało wyraźne odróżnienie sprawiedliwości rządzącej polis i moralności rządzącej jednostką. Dlatego z pojęcia sprawiedliwości wyrównawczej wyłączał on rozważanie intencji i cech moralnych, wyrównywanie winno następować niezależnie od oceny kwalifikacji indywidualnych sądzonych osób ${ }^{46}$. Odmienne stanowisko zajął stoicyzm. Wprowadzając ideę prawa uniwersalnego, przyjął, że nie jest to już prawo odnajdywane w porządku politycznym, ale reguły rządzące naturą. Odkrywa się je poprzez objawienie lub introspekcję, a nie roztropność nabywaną poprzez uczestnictwo w życiu politycznym. Dlatego stoicyzm, zdaniem Villeya, nie ma zasadniczo charakteru politycznego i jurydycznego, lecz moralny ${ }^{47}$. Ideę prawa uniwersalnego, niezmiennego, które mędrcy mają za zadanie odkrywać i ugruntowywać wśród ludu, na grunt prawa rzymskiego przeniósł Cyceron ${ }^{48}$. Skoro prawo jest odnajdywane w ludzkim rozumie, $w$ jego centrum zaczyna być umieszczany człowiek $^{49}$. Idea cycerońska nie zdołała, zdaniem Villeya, zdominować prawa rzymskiego. W chrześcijaństwie jednak sprawiedliwość przestaje być przede wszystkim kwestią właściwego urządzenia polis, a staje się nakazem bożym, skierowanym do każdej jednostki ${ }^{50}$. Taką koncepcję prawa przejęło średniowiecze ${ }^{51}$. Jawna „mora-

${ }^{43}$ H. Grocjusz, op. cit., s. 78-79; podobnie u Suareza - zob. R. Tuck, op. cit., s. 56-57. Z tego względu uważa się często Grocjusza za ideologa absolutyzmu i własności jako prawa absolutnego. Zdaniem Tucka kwestia ta nie jest jednoznaczna, skoro Grocjusz uważa, że można jednak stawiać opór władcy w sytuacjach wyjątkowych i że takie sytuacje mogą też uzasadniać wspólną własność - ibidem, s. 79-80.

44 T. Hobbes, op. cit., s. 299 n.

45 L. Strauss, op. cit., s. 175-176.

46 Arystoteles, op. cit., ks. V, 1132a.

47 M. Villey, op. cit., s. 404.

48 Ibidem, s. 412.

49 Skoro ma formę racjonalną, zaczyna być utożsamiane ze zbiorem jasnych reguł, z leges.

50 Dlatego też prawo naturalne zaczyna być określane jako część prawa prywatnego, tak jak u Ulpiana (początek Digestów, L. Strauss, op. cit., s. 134-135). Augustyn zakłada ścisłe połączenie i wyprowadzenie prawa z moralności - państwo chrześcijańskie jawi się jako jej strażnik - M. Villey, op. cit., s. 130-131.

51 Prawo we właściwym rozumieniu tego słowa to moralność wywiedziona z Pisma Świętego. Systemy prawa zwyczajowego, regulujące życie większości mieszkańców, jawiły się jako godne zachowania, jako wyrazy woli bożej, lecz niegodne analizy i pogłębionych komentarzy - M. Villey, op. cit., s. 136-137. Wyrazem powrotu do idei klasycznej była, według Villeya, koncepcja świętego Tomasza. 
lizacja” prawa następuje w czasach nowożytnych u Grocjusza. Wraca on do koncepcji stoickiej, w której źródłem prawa jest racjonalnie odnaleziona moralność. Podobnie u Lockea jako ograniczenia praw indywidualnych wskazywane są zasady postępowania $\mathrm{w}$ stosunkach $\mathrm{z}$ innymi osobami prywatnymi - nieszkodzenie im, wynagradzanie szkód itd. Jak zauważa Villey, wyprowadzanie, tak jak u Grocjusza, z moralności podstawowych reguły prawa naturalnego nadaje im, tak samo jak regułom moralnym, walor absolutny (tak jak nigdy nie należy wyrządzać drugiemu szkody, podobnie nigdy nie należy kraść, choćby z głodu itd. ${ }^{52}$. Uprawnienia naturalne winny być więc chronione niezależnie od kontekstu politycznego.

\section{Uprawnienie naturalne jako kryterium legitymizacji władzy politycznej - prawa człowieka}

Rezultatem uznania uprawnień naturalnych za źródło porządku politycznego jest przypisanie im funkcji kontrolnej wobec bieżącego działania władzy politycznej. Wyraziło się to w idei praw człowieka.

Pojęcie praw człowieka upowszechniło się we Francji w latach sześćdziesiątych XVIII wieku za sprawą Umowy społecznej Jeana-Jacques'a Rousseau ${ }^{53}$. Jednym z pierwszych aktów rewolucji francuskiej było ogłoszenie Deklaracji Praw Człowieka i Obywatela dnia 26 sierpnia 1789 roku. Przyjmuje ona realizację praw człowieka jako rację istnienia społeczeństwa politycznego, a ich przestrzeganie uznaje za kryterium jego legitymacji. Zgodnie $\mathrm{z}$ art. 2: „celem wszelkiego zrzeszenia politycznego jest utrzymanie przyrodzonych i niezbywalnych praw człowieka”, zaś w myśl artykułu szesnastego: „społeczeństwo, w którym rękojmie praw człowieka nie są zabezpieczone ani podział władzy nie jest ustalony, nie ma Konstytucji”.

Przekonanie to wyraził Thomas Paine, stwierdzając, że u źródeł każdego z praw obywatelskich leżą prawa naturalne, treściowo w pełni skonkretyzowane jeszcze

\footnotetext{
Miał on wyraźnie rozróżniać kwestie moralności i sprawiedliwości - zasadniczo do tych pierwszych odnosi się lex divina, do tych drugich - lex naturalis - ibidem.

52 Według Villeya sięgnięcie do stoicyzmu w celu tworzenia filozofii prawa było nieporozumieniem. Stoicy nie tworzyli filozofii prawa czy choćby moralności polityki, ale moralność prywatną, służącą samodoskonaleniu się jednostki. Powinności były określane jako absolutne, ponieważ nie chodziło o sprawiedliwe uregulowanie stosunków między ludźmi, lecz o osiągnięcie przez jednostkę doskonałości etycznej - w ten sposób na przykład obowiązkowi niewyrządzania szkody, ciążącemu również na głodującym, towarzyszył obowiązek humanitaryzmu ciążący na bogaczu. Zasady te przekształcone na zasady prawne usprawiedliwiały rodzący się kapitalizm - ibidem, s. 556. Moralność, jeśli stosować ją do rozsądzania stosunków między ludźmi, rodzi arbitralność i uzasadnia dowolną kazuistykę, tak jak krytykowane przez Pascala „urealnianie” przez jezuitów w XVII wieku zasad moralnych i wyprowadzanie z ogólnych zasad religii wielkiej ilości norm szczegółowych (a w rezultacie - usprawiedliwianie występków) - ibidem, s. 549-550.

53 L. Hunt, Inventing Human Rights, New York-London 2007, s. 23-24.
} 
przed ukonstytuowaniem się społeczeństwa politycznego. Prawa obywatelskie służą jedynie skuteczniejszej ochronie niektórych uprawnień naturalnych - tych, które mogą być lepiej chronione przez społeczeństwo niż samą jednostkę (na przykład prawa dotyczące zapewnienia sobie bezpieczeństwa; stąd prawo do sądu). Prawa obywatelskie nie mogą natomiast ograniczać ani unieważniać tych praw naturalnych, które nie potrzebują do swej lepszej ochrony praw wynikających z przynależności do społeczeństwa (wolności negatywne w granicach wolności innych - wolność dążenia do szczęścia, wolność sumienia, wolność słowa itd.) ${ }^{54}$. Opowiadając się za rządem minimalnym ${ }^{55}$, Paine odmawia władzy politycznej samoistnej logiki ${ }^{56}$. Twierdzi, że nawet jeśli społeczeństwo jest zorganizowane politycznie przez zabobon lub podbój, to w każdej chwili może wrócić do swego stanu pierwotnego, ustanawiając prawa zgodne $\mathrm{z}$ rozumem. Takim zrzeszeniem ludzi $\mathrm{w}$ stanie naturalnym jest, jego zdaniem, francuskie zgromadzenie narodowe w okresie rewolucji ${ }^{57}$. Paine, chociaż uznawał pierwotność praw człowieka wobec władzy politycznej, postrzegał deklarację z 1789 roku nie tyle za gwarancję konkretnych wolności, ale ustanowienie podstaw porządku politycznego. Wskazywał, że wszystkie jej zapisy mieszczą się $\mathrm{w}$ istocie $\mathrm{w}$ trzech pierwszych artykułach wyrażających najbardziej fundamentalne prawa człowieka - wolność, równość, własność, bezpieczeństwo i prawo do przeciwstawiania się uciskowi, wskazujących te prawa jako cel wspólnoty politycznej oraz artykułujących zasadę, że wszelka suwerenność leży w narodzie. Pozostałe, bardziej skonkretyzowane zapisy, są, jak uważa Paine, uzasadnione szczególną sytuacją, w której znajduje się wyzwalająca się z ucisku i zepsucia Francja, musząca zapewnić sobie ochronę odzyskanej wolności (wyraźnie wskazana zostaje więc ideologiczno-praktyczna funkcja deklaracji).

Uznanie praw człowieka nie tylko za rację istnienia wspólnoty politycznej, ale i cel działania władzy politycznej uzasadnia postulat, by przy rozważaniu możliwości ich realizacji abstrahować od aktualnego stanu relacji społecznych, a odwoływać się przede wszystkim do możliwości ludzkiej woli. Przekonanie to znalazło wyraz w koncepcji Immanuela Kanta. Na gruncie jego filozofii wolne działanie jest istotą zarówno moralności, jak i stanu prawnego oraz ustroju republikańskiego. Wolne działanie polega wprawdzie na działaniu zgodnym z rozumnymi zasada-

54 „Civil power properly considered as such is made up of the aggregate of that class of the natural rights of man" - T. Paine, The Rights of Man, http://www.ushistory.org/PAINE/rights/index.htm (dostęp: 15.04.2014).

55 O koncepcji T. Paine’a w kontekście idei społeczeństwa obywatelskiego pisze Wiesław Bokajło - idem, Społeczeństwo obywatelskie: sfera publiczna jako problem teorii demokracji, [w:] Społeczeństwo obywatelskie, red. W. Bokajło, K. Dziubka, Wrocław 2001, s. 17-83.

56 Krytykując zwolenników tradycyjnego pojmowania władzy, T. Paine w The Rights of Man pisze: „In all cases they took care to represent government as a thing made up of mysteries, which only themselves understood; and they hid from the understanding of the nation the only thing that was beneficial to know, namely, That government is nothing more than a national association adding on the principles of society".

57 T. Paine, op. cit. 
mi, tym niemniej u Kanta zasady te nie są wywiedzione z założeń określających cel człowieka w sensie metafizycznym, z wyjątkiem formalnie określonego celu, jakim jest realizacja wolności. W sferze moralnej wolność polega na kierowaniu się wolą moralną, czego oznaką ma być realizacja imperatywu kategorycznego ${ }^{58}$. Dla prawa, w odróżnieniu od moralności, nie ma znaczenia pobudka, którą kieruje się podmiot, realizując je: „prawo jest zatem ogółem warunków, pod którymi wola jednego (człowieka) daje się połączyć wolą innego zgodnie z pewną ogólną normą wolności” ${ }^{9}$; „prawo w ścisłym sensie można przedstawić także jako możliwość powszechnego wzajemnego przymusu dającego się pogodzić z wolnością, jaka przysługuje każdemu w granicach powszechnych norm" ${ }^{\text {" }}$. Co do wolności w sferze politycznej to, jak pisze Kant,

jej zasadę odnośnie do ustroju społeczeństwa wyrażam w następującej formule: nikt nie może zmusić mnie do bycia szczęśliwym na jego modłę (tak jak on sobie wyobraża pomyślność kogoś innego), lecz każdemu wolno poszukiwać szczęścia na tej drodze, która jemu samemu wydaje się najlepsza, jeśli tylko nie przynosi on przez to uszczerbku wolności innych, dążących do podobnego celu wolności połączonej pewnym możliwym, powszechnym prawem $\mathrm{z}$ wolnością wszystkich ${ }^{61}$.

Zrealizowanie ustroju republikańskiego może być więc jedynie skutkiem wolnej woli jednostek realizujących swoje indywidualne cele. Skłania to racjonalistycznego filozofa do zaprezentowania profetycznej idei historii. Według Kanta przyszłości rodzaju ludzkiego nie można przewidzieć metodami nauk przyrodniczych; ludzie nie kierują się wyłącznie instynktem. Historię tworzą jednostki obdarzone wolną wolą; nie można na podstawie historii pojętej jako zbiór faktów stwierdzić, że wola ta jest dobra lub zła ${ }^{62}$. Rozpatrując możliwości zapanowania ustroju republikańskiego, w którym urzeczywistni się stan prawny, należy odwołać się do historii przepowiadającej zdarzenia, „wróżebnej”, której proroctwa mogą się sprawdzić dzięki zachowaniu samego przepowiadającego: „Jak jednak jest możliwa historia a priori? Odpowiadamy: wtedy, gdy wróżbita sam tworzy i wywołuje zdarzenia, które przepowiada"63. Jawi się ona jako historia gatunku ludzkiego pojętego jako ogół ludzi wolnych, a nie jako gatunek rozpatrywany z perspektywy determinizmu biologicznego ${ }^{64}$. Celem tak rozumianej ludzkości jest rozwój racjonalności człowieka. Postęp w tej dziedzinie może być osiągnięty tylko wtedy, gdy

58 I. Kant, Ugruntowanie metafizyki moralności, przeł. P. Zarychta, Kraków 2005, s. 70 n.

59 I. Kant, Metafizyczne podstawy nauki prawa, przeł. W. Galewicz, Kęty 2006, s. 42.

60 Ibidem, s. 44.

${ }^{61}$ I. Kant, Rozprawy z filozofii historii, przeł. T. Kupś et al., Kęty 2005, s. 130. W kolejnej definicji wolność polityczną Kant określa jako „uprawnienie, by nie podlegać żadnym zewnętrznym prawom oprócz tych, na które mógłbym wyrazić swą zgodę" - ibidem, s. 171.

62 Ibidem, s. 32, 212-213.

63 Ibidem, s. 32, 209.

${ }^{64}$ Ibidem, s. 209. 
zapanuje ustrój republikański ${ }^{65}$ - należy więc w interpretacji historii przyjąć, że celem gatunkowym człowieka jest jego zbudowanie ${ }^{66}$.

Kant wskazuje, że osiągnięcie stanu pełnego, wzajemnego poszanowania wolności jest obecnie niemożliwe: „Z drewna krzywego jak to, z którego jest zrobiony człowiek, nie można wystrugać nic prostego. Dlatego przyroda kazała nam tylko zbliżać się do tej idei”67. Pojawia się więc idea swoistej „chytrości historii” — człowiek będzie przekraczał zastany stan stosunków społecznych, kierując się dążeniem do wolności, a nie doskonałości moralnej; rolą filozofa jest przyśpieszenie tego procesu poprzez prawidłową jego interpretację. W perspektywie historii „wróżebnej” ludzie dążą do ustroju republikańskiego, nie tyle kierując się naturalnymi uczuciami miłości czy też uczuciowymi więziami ukonstytuowanymi na podstawie wspólnych symboli, co swoją „aspołeczną towarzyskością”. Człowiek jest istotą społeczną w tym sensie, że ma świadomość, że jego zdolności mogą rozwinąć się tylko w społeczeństwie, a zarazem aspołeczną, ponieważ chce w nim wszystko urządzić na własny sposób. Żyjąc wśród innych, których może nienawidzić, jest w stanie być wolnym w granicach prawa, wypełniając je, dlatego jednostki, zbliżając się do stanu pogodzenia wolności indywidualnych, mogą wejść w stan obywatelski ${ }^{68}$. Nieistotne jest więc, czy natura ludzka się poprawi i zwiększy się ilość czynionego dobra - ważne, że ludzie będą coraz bardziej przestrzegać prawa, bez względu na swoje pobudki ${ }^{69}$. Postęp polega więc na osiąganiu stanu prawnego, pojawianiu się zewnętrznych objawów legalności, a nie na postępie moralnym:

65 Ustrój republikański to „ustrój ustanowiony, po pierwsze, na zasadach wolności członków społeczeństwa (jako ludzi), po drugie, na podstawowych zasadach zależności wszystkich od jednego, wspólnego prawodawstwa (jako poddanych), po trzecie, na prawie równości tychże jako obywateli państwa - jedyny (ustrój), który wynika z idei umowy pierwotnej, na której musi być ugruntowane wszelkie prawne ustawodawstwo narodu — jest ustrojem republikańskim” — ibidem, s. 171.

66 „Idea konstytucji współbrzmiącej z naturalnymi prawami ludzi, zgodnie z którą ci, którzy należą do przestrzegających prawa, będąc zjednoczeni, sami powinni być prawodawcami, leży u podstaw wszelkich form państwowości, zaś wspólnota, która zgodnie z tą ideą została pomyślana przy użyciu czystych pojęć rozumu, zwie się platońskim ideałem (respublica noumenon) i nie jest pustym wymysłem, lecz wiecznie zapobiegającą wszelkim wojnom normą dla każdego obywatelskiego ustroju. Zorganizowane zgodnie z tym społeczeństwo obywatelskie prezentuje sobą przykład takiego ustroju osiągnięty drogą doświadczenia (respublica phaenomenon), do którego można dojść dopiero po licznych bojach i wojnach" - ibidem, s. 218-219. Podstawowe znaczenie ma sposób interpretacji historii, który może przybliżać do tego celu. „Historię ludzkości jako całość uważać można za spełnienie ukrytego planu przyrody, by stworzyć wewnętrznie, zaś dla realizacji tego celu również zewnętrznie, doskonały ustrój jako jedyny stan, w którym może ona rozwinąć wszystkie dane ludzkości predyspozycje” - ibidem, s. 40. „Filozoficzna próba opracowania historii powszechnej (rozumianej) jako realizacja planu przyrody mającego na celu doskonałe, obywatelskie zjednoczenie całego ludzkiego rodzaju, musi być uznana za możliwą, a także za potrzebną dla owych zamiarów przyrody" - ibidem, s. 41.

67 Ibidem, s. 36-37.

68 Ibidem, s. 34.

${ }^{69}$ Ibidem, s. 219. 
plonu (rezultatu) pracy ludzkiego rodzaju nad tym, by być lepszym poszukiwać należy nie we wciąż wzrastającym quantum moralności, w usposobieniu, lecz w pomnożeniu produktów jej legalności, w uczynkach zgodnych w obowiązkiem bez względu na to, przez jakie pobudki mogłyby one być stymulowane ${ }^{70}$.

$\mathrm{W}$ ich realizacji podstawowe znaczenie ma rozwój wykształcenia ${ }^{71}$. Tym niemniej przejście do ustroju republikańskiego nie będzie wyłącznie wynikiem wyrachowania - o zbliżaniu się do stanu republikańskiego świadczyć ma reakcja na rewolucję francuską. Ku optymizmowi winien skłaniać bezinteresowny entuzjazm (który sam w sobie, jako emocja, „nie da się w pełni usprawiedliwić”), wywołany przez „czyste pojęcie prawa”, jaki ona wzbudziła ${ }^{72}$. W tym sensie rewolucja z 1789 roku jawi się jako znak dziejowy ${ }^{73}$. Rewolucja ta, nawet jeśli się nie powiedzie, przyniesie zło lub powrót do stanu poprzedniego, pozostanie dowodem postępu ludzkości. Postęp, rozważany w perspektywie ogólnoludzkiej, gatunkowej, nie jest, zdaniem Kanta, wyrazem oderwanego od rzeczywistości idealizmu, lecz obiektywnym faktem ${ }^{74}$.

Założenie naturalności praw człowieka i uznanie ich za nadające się do praktycznego zastosowania kryterium legitymizacji władzy politycznej nie musi prowadzić do postulatu jej ograniczenia. Wręcz przeciwnie - jeśli prawa człowieka oderwać od tradycji i więzi społecznej, a następnie utożsamić z wolą narodu, to mogą one, jak wykazała ideologia i praktyka rewolucji francuskiej, uzasadniać swobodne kształtowanie społeczeństwa przez państwo, zaś ich przekraczający charakter generować ma płynność rzeczywistości społecznej, wymagającej ciągłego formowania przez władzę.

W tym miejscu należy odwołać się do rozważań Hannah Arendt. Podkreśla ona różnicę między amerykańską (1776 rok) a francuską deklaracją praw. Ta pierwsza miała chronić przed nadużyciami władzy prawa jednostki już wyposażonej w status polityczny. Druga ustanawiała prawa człowieka i obywatela jako fundament społeczeństwa politycznego, traktując jednostkę jako istotę naturalną, niepolityczną ${ }^{75}$. Różny był więc sposób rozumienia źródła władzy politycznej. Rewolucja amerykańska wywodzi władzę centralną z wielkiej ilości władz lokalnych: komitetów, władz hrabstw, władz stanowych. Była to, zdaniem Arendt, realna podstawa legitymizacji, zapewniająca stabilność. Rewolucja francuska wyprowadzała legitymizację władzy z woli narodu: fikcji, którą nie dało się na gruncie ideologii rewolucyjnej skonkretyzować pod groźbą utożsamienia „woli powszechnej” z wolą empirycznie istniejącej grupy ludzi - „wolą wszystkich”. Skutkiem braku ponadpolitycznego autorytetu (którego rolę w USA pełni Konstytucja) jest charaktery-

\footnotetext{
70 Ibidem.

71 Ibidem, s. 217 n.

72 Ibidem, s. 214-215.

73 „Signum rememorativum, demonstrativum, prognosticon” - ibidem, s. 213.

74 Ibidem, s. 216-217.

75 H. Arendt, O rewolucji, przeł. M. Godyń, Warszawa 2003, s. 133-134.
} 
zujące rewolucję francuską utożsamienie źródła władzy i źródła prawa ${ }^{76}$. Źródłem prawa nie jest już, tak jak według Arendt było w starożytności, przemyślane uzgodnienie, świadomy wybór dokonany w drodze wspólnego rozumowania i wzajemnego przekonywania, lecz wola. Co więcej, nie jest to wola większej liczby obywateli, lecz „wola powszechna”. Wola w znaczeniu uzgodnienia zakładała uprzednie istnienie społeczności politycznej, wola powszechna dopiero ją tworzy ${ }^{77}$. Nie jest ona związana z partykularnym interesem, który może być wyrażony na scenie publicznej; aby kierować się wolą powszechną, trzeba w sobie zwalczyć wolę partykularną - tę właśnie, która zakotwiczyła politycznie rewolucję amerykańską ${ }^{78}$. Paradoksalnie niepolityczny charakter rewolucji francuskiej przejawia się w tym, że w przeciwieństwie do rewolucji amerykańskiej nie przyjęła ona za swe hasło dążenia do szczęścia, lecz do wolności. Tymczasem, zdaniem Arendt, to właśnie dążenie do szczęścia we wspólnocie politycznej poprzez rywalizację, porównywanie się, wzajemne oddziaływanie konstytuuje istotę polityczności ${ }^{79}$. Rewolucja francuska (według Arendt) odeszła od jedynego, właściwego rozumienia wolności, to jest rozumienia jej jako równej możliwości działania politycznego. Zidentyfikowała ją natomiast $\mathrm{z}$ równością naturalną — przypisaną ludziom cechą, która ma być niezależna od ich wyrażania się na scenie publicznej. W ten sposób, nawet jeśli „burżuazyjna” rewolucja francuska nie posługiwała się, w szerokim zakresie, hasłami równości ekonomicznej, to jednak otworzyła drogę do ich formułowania. Wprowadziła w ten sposób do polityki masy podległe konieczności biologicznej, wynikającej z nędzy. Tymczasem kwestie te są obce polityce, domenie wolności. Wprowadzenie do polityki kwestii socjalnej wyzwala litość i współczucie - uczucia apolityczne, wymagające pełnego zrealizowania ${ }^{80}$. Cele te, jako niepolityczne, mogą być zrealizowane tylko drogą przemocy, dlatego nie można stawiać granic w dążeniu do nich; uzasadniają one absolutyzm ideologiczny i fanatyzm w działaniu. Skoro największym występkiem staje się „hipokryzja”, odrzucone zostaje konstytutywne dla polityki odgrywanie roli ${ }^{81}$.

Dążenie do wolności publicznej, identyfikowanej z wyzwoleniem ludu z nędzy, ciągłym stanem nowego początku przejawiło się w stanie rewolucji permanentnej - jedynym stanie, w którym, w perspektywie rewolucji francuskiej, wolność pojęta jako realizacja woli powszechnej może się wyrazić ${ }^{82}$. Dlatego w rewolucyjnej i porewolucyjnej Francji władza cierpiała na ciągły brak legitymizacji - stąd ciągłe przewroty polityczne i zmiany konstytucji. Skoro nie przyjmowano rozróżnie-

\footnotetext{
76 Ibidem, s. 200-211.

77 Ibidem, s. 91.

78 Ibidem, s. 91-94.

79 Ibidem, s. 147-148.

80 Ibidem, s. 69 n.

81 Ibidem, s. 117 n.

82 Ibidem, s. 164-167.
} 
nia na władzę i przemoc, energia ludu znajdującego się w stanie przedpolitycznym, naturalnym, uniemożliwiła ukonstytuowanie się trwałego porządku ${ }^{83}$.

Rozważania Arendt na temat niestabilności legitymizacji władzy w rewolucyjnej Francji korespondują z jej koncepcją totalitaryzmu. Dla Arendt właśnie idea praw człowieka, legitymizujących władzę polityczną, a zarazem utożsamionych z wolą ludu, była, jako bezproduktywna polityczna fikcja, wyrazem słabości państwa liberalno-demokratycznego. Uzasadniając jego depolityzację, była jednym z czynników, które doprowadziły do pojawienia się totalitaryzmu, w którym płynność i niekończący się ruch „społeczeństwa” unicestwia zarówno indywidualność, jak i wszelkie symbole i punkty odniesienia stabilizujące wcześniej sferę polityczną ${ }^{84}$.

Idea uprawnień naturalnych ma swe źródło w idei prawa naturalnego. Jest jednak zarazem odejściem od jego pojmowania jako obiektywnego porządku rzeczy na rzecz uznania go za wyraz woli - najpierw Boga, następnie jednostek. W XVII i XVIII wieku upowszechniły się koncepcje zakładające, że treścią praw naturalnych jest realizacja pragnień człowieka związanych z jego egzystencją biologiczną. Uznano ją zarazem za źródło porządku politycznego. W idei praw człowieka realizacja tak pojętych uprawnień naturalnych jawi się jako kryterium kontroli władzy politycznej. Jak wskazuje H. Arendt, uznanie za źródło porządku politycznego praw pojmowanych jako niezależne od instytucji umożliwiających działanie polityczne prowadzi do destabilizacji sfery publicznej, utożsamienia władzy z przemocą, a w rezultacie do zaniku indywidualności, jaki miał miejsce $\mathrm{w}$ totalitaryzmie. Otwarte pozostaje pytanie o możliwość pojmowania uprawnień naturalnych w sposób, który godziłby je z istnieniem wcześniejszego od nich porządku politycznego.

\section{Bibliografia}

Arendt H., Korzenie totalitaryzmu, przeł. D. Grinberg, M. Szawieł, Warszawa 2008.

Arendt H., O rewolucji, przeł. M. Godyń, Warszawa 2003.

Arystoteles, Etyka, przeł. D. Gromska, Warszawa 2012.

Bokajło W., Społeczeństwo obywatelskie: sfera publiczna jako problem teorii demokracji, [w:] Społeczeństwo obywatelskie, red. W. Bokajło, K. Dziubka, Wrocław 2001.

Douzinas C., The End of Human Rights, Oxford 2000.

Grocjusz H., Trzy Księgi o Prawie Wojny i Pokoju, w których znajdują wyjaśnienie Prawo Natury i Prawo Narodów a także Główne Zasady Prawa publicznego, przeł. R. Bierzanek, Warszawa 1957. Habermas J., Theory and Practice, przeł. J. Viertel, Boston 1974.

Hobbes T., Lewiatan, czyli materia, forma i władza państwa kościelnego i świeckiego, przeł. C. Znamierowski, Warszawa 2009.

83 Ibidem, s. 223-227.

${ }^{84}$ H. Arendt, Korzenie totalitaryzmu, przeł. D. Grinberg, M. Szawieł, Warszawa 2008, s. 645-670. 
Hunt L., Inventing Human Rights, New York-London 2007.

Kant I., Metafizyczne podstawy nauki prawa, przeł. W. Galewicz, Kęty 2006.

Kant I., Rozprawy z filozofii historii, przeł. T. Kupś et al., Kęty 2005.

Kant I., Ugruntowanie metafizyki moralności, przeł. P. Zarychta, Kraków 2005.

Locke J., Dwa traktaty o rzadzie, przeł. Z. Rau, Warszawa 1992.

Paine T., The Rights of Man, http://www.ushistory.org/PAINE/rights/index.htm.

Rau Z., Wstęp, [w:] J. Locke, Dwa traktaty o rządzie, Warszawa 1992.

Strauss L., Prawo naturalne w świetle historii, przeł. T. Górski, Warszawa 1969.

Tierney B., The Idea of Natural Rights: Studies on Natural Rights, Natural Law and Church Law 11501625, Cambridge 2001.

Tomasz z Akwinu, Suma teologiczna, http://katedra.uksw.edu.pl/suma/suma_przelad.htm.

Tuck R., Natural Right Theories, Lexington 2011.

Villey M., La formation de la pensée juridique moderne, Paris 2003. 